\title{
Hydroxyapatite in Materials for Medical Applications
}

Drahomir Dvorsky, Jiri Kubasek, Dalibor Vojtěch

Faculty of chemical technology, department of metals and corrosion engineering, UCT Prague, Technická 516628 Praha 6 - Dejvice, Czech Republic. E-mail: dvorskyd@ vscht.cz

Hydroxiapatite is ceramic material with properties and composition similar to the bone tissue. This makes it a suitable choice for biomaterials. However, hydroxyapatite alone has poor mechanical properties. Present paper shows two possible applications of hydroxyapatite in materials intended for medical applications. 1. Hydroxyapatite can be used as a layer which causes the material to be more bioactive. In this article the layer of HA is applied on WE43 by plasma spraying and structure, composition and adhesive properties are measured. 2. Hydroxyapatite can serve as reinforcement in metallic composite materials. Present work sum up properties of composite materials with 2,5 and $10 \mathrm{wt} . \%$ of $\mathrm{HA}$ that were prepared by powder metallurgy route. The structure, hardness and compressive mechanical properties are characterized.

Keywords: Hydroxyapatite, magnesium, composite, plasma, coating.

\section{Aknowledgement}

Authors wish to thank the Czech Science Foundation (project no. P108/12/G043) and specific university research (MSMT no. 22/2015) for the financial support of this research.

\section{References}

[1] WITTE, F., FEYERABEND, F., MAIER, P., FISCHER, J., STÖRMER, M., BLAWERT, C., DIETZEL, W., HORT, N. (2007). Biodegradable magnesium-hydroxyapatite metal matrix composites. Biomaterials, 28 (13), 2163-2174.

[2] DASGUPTA, S., TARAFDER, S., BANDYOPADHYAY, A., BOSE, S. (2013). Effect of grain size on mechanical, surface and biological properties of microwave sintered hydroxyapatite. Materials Science and Engineering: C, 33 (5), 2846-2854.

[3] THUAULT, A., SAVARY, E., HORNEZ, J. C., MOREAU, G., DESCAMPS, M.; MARINEL, S.; LERICHE, A., Improvement of the hydroxyapatite mechanical properties by direct microwave sintering in single mode cavity. Journal of the European Ceramic Society 2014, 34 (7), 1865-1871.

[4] YUSOP, A. H., BAKIR, A. A., SHAHAROM, N. A., ABDUL KADIR, M. R., HERMAWAN, H. (2012). Porous biodegradable metals for hard tissue scaffolds: a review. Int. J. Biomater., 641430, $10 \mathrm{pp}$.

[5] SOPYAN, I., MEL, M., RAMESH, S., KHALID, K. A. (2007). Porous hydroxyapatite for artificial bone applications. Science and Technology of Advanced Materials, 8 (1-2), 116-123.

[6] FARROKHI-RAD, M., LOGHMANI, S. K., SHAHRABI, T., KHANMOHAMMADI, S. (2014). Electrophoretic deposition of hydroxyapatite nanostructured coatings with controlled porosity. Journal of the European Ceramic Society, 34 (1), 97-106

[7] FAUCHAIS, P. (2004). Understanding plasma spraying. Journal of Physics D: Applied Physics, 37 (9), R86.

[8] ZHAO, G.-L., WEN, G.-W., WU, K. (2009). Influence of processing parameters and heat treatment on phase composition and microstructure of plasma sprayed hydroxyapatite coatings. Transactions of Nonferrous Metals Society of China, 19, Supplement 2, s463-s469.

[9] VILOTIJEVIĆ, M., MARKOVIĆ, P., ZEC, S., MARINKOVIĆ, S., JOKANOVIĆ, V. 2011). Hydroxyapatite coatings prepared by a high power laminar plasma jet. Journal of Materials Processing Technology, 211 (6), 9961004. 